\title{
Course-based Undergraduate Research Experience in a Senior Cell \& Molecular Biology Laboratory Course
}

\author{
Laura L. Atkinson
}

\author{
Mount Royal University, Department of Biology,4825 Mount Royal Gate SW, Calgary AB T3E \\ 6K6 CAN \\ (latkinson@mtroyal.ca)
}

\begin{abstract}
Course-based undergraduate research experiences (CUREs) offer students the ability to experience research during their undergraduate studies. While independent studies projects have generally achieved this in the past, demand for undergraduate research positions exceeds their availability at most institutions leading to the rise in popularity of CUREs. This poster explores the use of a CURE in a fourth year Cell \& Molecular Biology laboratory course. In this course, students used a cell culture model to investigate an aspect of the morphological and biochemical alterations that occur during the process of myogenesis. Over the semester, students identified a specific research question, designed a series of experiments, collected and analyzed their data and presented their research in the form of a manuscript and presentation. Although set assessment dates aimed for completion of certain experiments, grading focused on students having gone through the scientific process and their ability to troubleshoot when experiments didn't work. This type of assessment challenged them to integrate fundamental background knowledge from their previous courses with critical thinking and advanced research methodology. Overall, CUREs are effective in exciting and engaging the students as well as providing them with a unique undergraduate research experience.
\end{abstract}

Keywords: CURE, cell culture

Link to Original Poster File: https://doi.org/10.37590/able.v41.poster57

\section{Mission, Review Process \& Disclaimer}

The Association for Biology Laboratory Education (ABLE) was founded in 1979 to promote information exchange among university and college educators actively concerned with teaching biology in a laboratory setting. The focus of ABLE is to improve the undergraduate biology laboratory experience by promoting the development and dissemination of interesting, innovative, and reliable laboratory exercises. For more information about ABLE, please visit http://www.ableweb.org/.

Advances in Biology Laboratory education is the peer-reviewed publication of the conference of the Association for Biology Laboratory Education. Published articles and extended abstracts are evaluated and selected by a committee prior to presentation at the conference, peer-reviewed by participants at the conference, and edited by members of the ABLE Editorial Board. Published abstracts are evaluated and selected by a committee prior to presentation at the conference.

\section{Citing This Article}

Atkinson LL. 2020. Course-based undergraduate research experience in a senior cell \& molecular biology laboratory course. Article 57 In: McMahon K, editor. Advances in biology laboratory education. Volume 41. Publication of the 41st Conference of the Association for Biology Laboratory Education (ABLE). https://doi.org/10.37590/able.v41.abs57

Compilation (C 2020 by the Association for Biology Laboratory Education, ISBN 1-890444-17-0. All rights reserved. Nopart of this publication may be reproduced, stored in a retrieval system, or transmitted, in any form or by any means, electronic, mechanical, photocopying, recording, or otherwise, without the prior written permission of the copyright owner. 
ABLE strongly encourages individuals to use the exercises in this volume in their teaching program. If this exercise is used solely at one's own institution with no intent for profit, it is excluded from the preceding copyright restriction, unless otherwise noted on the copyright notice of the individual chapter in this volume. Proper credit to this publication must be included in your laboratory outline for each use; a sample citation is given above. 